\title{
Мा

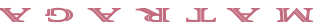 \\ Limiares do literário: uma aproximação entre Llansol e Lispector
} NII

\author{
Maria Lúcia Wiltshire de Oliveira \\ Universidade Federal Fluminense
}

https://orcid.org/0000-0003-1580-176X

\section{RESUMO}

Embora a escrita seja um artefato humano que elide ou põe entre parênteses o sujeito, deparamo-nos com situações limítrofes que ao romperem os paradigmas dos gêneros da prosa - no caso aqui, a ficção e as formas confessionais -, revelam dilemas que instabilizam o discurso literário produzido pelo imaginário. Com o objetivo de observar o limiar desta instabilidade, o trabalho pretende revisitar a postulação de diferença entre o literário e o não-literário para refletir sobre as distinções entre narrativa (escrita do outro) e o diário (escrita de si). De modo resumido, a análise repousa em dois binômios - real vs. ficcional, eu vs. outro - que serão discutidos frente ao desafio de Blanchot ao sugerir um "lugar da imantação", passagem que opõe narrativa ao diário. Na perspectiva de Peirce, a imagem é um hipo-ícone ou um quase-ícone que mantém com o real uma relação estreita de semelhança, que garante a sua independência em relação ao real e ao sujeito que supostamente lhe poderiam servir, respectivamente, de cenário prévio ou de suporte autoral. Em torno destes conceitos, pretende-se discutir a imagem como unidade mínima do "belo" e seu efeito do "novo". O corpus principal de discussão contempla excertos da escrita de duas autoras, extraídos das obras Uma data em cada mão; Livro de Horas I da portuguesa Maria Gabriela Llansol e Um sopro de vida; Pulsações da naturalizada brasileira Clarice Lispector.

PALAVRAS-CHAVE: Limiar; Imagem; Voz narrativa; Llansol; Lispector

\section{Literary Thresholds: an appoach between Llansol and Lispector}

\section{ABSTRACT}

Although writing is a human artefact that eliminates or puts the subject in parentheses, we are faced with borderlines situations that break the paradigms of the genres of prose - in this case, fiction and confessional formas -, and reveal dilemmas that give instability to the discourse literary produced by the imaginery. In order to observe the threshold of this instability, the work intends to revisit the postulation of difference between the literary and the non-literary to reflection on this distinctions between narrative (the other's wriiting) and the diary (self-writing). In summary, the analysis rests on two binomials - real vs ficcional, me vs another which will be discussed in the face of Blanchot's challenge when suggesting a "place of magnetization", a passage that opposes narrative to diary. In Peirce's perspective, the image is a hypo-icon or a quase-icon that maintains close relationship with the real and the subject that supposedly could serve, respectively, as a scenario previous or authorial support. Around theses concepts, it is intended to discuss the image as a minimum unit of the "beautiful" and its effect of the "new". The discussion corpus includes excerpts of two works: Uma data em cada mão; Livro de Horas I by the Portuguese Maria Gabriela Llansol and Um sopro de vida; Pulsações by the naturalized Brazilian Clarice Lispector.

KEYWORDS: Threshold; Image; Narrative voice; Llansol; Lispector 
Não é fácil dar conta das manifestações exteriores de um trabalho íntimo.

(LLANSOL, 2009, p.189)

Não faço literatura: eu apenas vivo ao correr do tempo.

(LISPECTOR, 1999, p. 16)

A

proposta do título aborda os desafios teóricos para o entendimento de dois binômios que costumam marcar o "limite" entre a linguagem comum e a literária. Sobre o primeiro binômio - "realidade vs. imaginário" - centrado no objeto da representação, há uma longa tradição clássica de Platão a Nietzsche que o emprega, mutatis mutandi, para assinalar a distinção entre "verdade" e "mentira" no sentido moral dos discursos. O segundo binômio - "eu vs. outro" - voltado para a origem e a natureza da autoria, remonta a discussões da era moderna quando as musas abandonaram o seu protagonismo autoral na produção da obra. Em ambos os casos tais diferenças foram problematizadas nas vanguardas do início do século XX e, mais recentemente, nos movimentos pós-estruturalistas e pós-modernistas dos anos 70-801.

Com o objetivo de rever o conceito de "limite" em favor da noção de "limiar", retomamos algumas reflexões sobre a imagem literária como instabilizadora da distinção postulada no binômio entre o real e o imaginário baseando-nos em Peirce e Blanchot. Em direção análoga recuperamos ainda a teorização blanchotiana sobre "voz narrativa" como possibilidade de superação da diferença entre o eu e o outro. Desse modo, duas perguntas orientam o percurso do trabalho: 1) é possível conceber a imagem literária como o mais mutante dos signos sob um alongado (e talvez infinito) limiar de representação? b) é razoável supor que, de modo correlato, o sujeito da representação exista apenas como função transitória em deslocamento por entre as categorias da enunciação?

Se os dois binômios pertencem à ordem da representação, é de se postular necessariamente três fatores: a realidade, a imagem e o sujeito ou, em termos peirceanos, o objeto/referente, o signo e o interpretante como vértices da experiência semiótica triádica. Examinaremos mais de perto algumas categorias correlatas a esta questão, para depois ensaiar uma leitura dos "desregramentos" de Llansol e Lispector quanto ao uso do real e de si mesmas em alguns excertos de alta indiscernibilidade quanto ao gênero.

\section{Imagem e voz}

A tentativa de compreender a representação na tradição filosófica ocidental seguiu os termos das duas dicotomias, desprezando-se a difícil questão de saber o que transcorre entre ambas para além de uma visão antropocêntrica do mundo. Ao deixar de fora concepções que recaem na figura do Belo (ou equivalente) para atribuir especificidade à Arte e na do Artista como sujeito

\footnotetext{
1 Para marcar a diferença entre Modernismo e Pós-Modernismo, Ihab Hassam usou binômios opositivos em sua obra The dismemberment of Orpheus (citado em HARVEY, David 1992, p. 48).
} 
inventor - que em Kant receberam um golpe final ${ }^{2}$ - serão aqui privilegiadas duas contribuições teóricas que se aproximam entre si e que, em certa medida, abrem uma possibilidade de reflexão sobre tal lacuna: a de Maurice Blanchot, de natureza crítico-filosófica, ao tramitar pelos conceitos de "imagem" e de "voz narrativa"; e a de Charles Sanders Peirce, de fundo lógico-semiótico, sobre a noção de "imagem" como um "qualissigno".

O conceito de "imagem" em Blanchot escapa da retórica da representação como aquilo que só se assemelha a si mesmo, numa dessemelhança total com a realidade-objeto. Na sequência do pensamento de Hölderlin e Mallarmé, a palavra literária procederia da morte do real e surgiria como a vida dessa morte, algo novo "neste êxtase que é a imagem" (Blanchot, 1987, p. 263) que aparece em decorrência da supressão dupla, do eu e do mundo, no sentido da negatividade pensada por Hegel e explicitada por Agamben como o “inacessível' à linguagem” quando discute o indizível, "este não-dito, em si, [que] é simplesmente um negativo e um universal" (AGAMBEN, 2006, p. 27).

Na Ideoscopia ${ }^{3}$ de Peirce a "imagem" pertence à categoria do "ícone" que numa escala sígnica representacional ocupa o lugar oposto ao "símbolo" e a meia distância do "índice". A marca do "ícone" em relação ao objeto representado é a semelhança, assim como a contiguidade e a aleatoriedade marcam a relação do "índice" e do "símbolo", respectivamente, com os objetos. A “imagem” é um tipo especial de "ícone" que não depende da realidade pré-existente, já que, "através de sua observação direta, outras verdades relativas ao seu objeto podem ser descobertas além das que bastam para determinar sua construção" (PEIRCE, 2000, p. 65). Desse modo, "Em vez de identidade (o qualissigno) possui grande similaridade" (PEIRCE, 1974, p. 124) e daí decorrem a variabilidade (ou mutação) e o teor qualitativo da "imagem" como um (novo) "quase-objeto".

Por sua vez, a noção de 'voz narrativa" de Blanchot se refere àquele "outro eu neutro' e "de fora" que no passado era atribuído às musas como "a coerência impessoal de uma história" ["la cohérence impersonelle d'une histoire" (BLANCHOT, 1969, p. 558)] e que não se confunde com o autor nem com qualquer dos narradores representados. Fruto da consciência que se deixa encher "por uma plenitude anônima" (BLANCHOT 1987, p. 264), trata-se da voz do imaginário (ou da ficção) que supostamente não se confunde com o eu da linguagem comum e muito menos com o autor ele-mesmo. Seja pura alteridade, seja expressão fantasmática, esta voz não vem de outro mundo, mas tende a se ausentar naquele que a porta. Ela não se opõe a um suposto "eu" pré-estabelecido que comanda a palavra não-literária e, não exatamente ao contrário, desliza em vários tons entre o "eu" e o "outro", esfumando a oposição entre as duas categorias.

Quanto à natureza autoral do signo, o sistema peirceano supera a relação diádica e opositiva do tipo significante/significado entre o Signo e seu Objeto, criando o terceiro vértice, chamado "interpretante", onde se dá a função sujeito que permite uma analogia com a "voz narrativa" de Blanchot.

\footnotetext{
2 A contribuição de Kant vai além do Belo ao detectar a própria incognoscibilidade do mundo ou "a morte dos referenciais" que a física atômica confirmou depois, segundo COSTA LIMA (1974, p. 37).

${ }^{3}$ A Ideoscopia peirceana subentende três universos: 0 da Primeiridade, feito de qualidades; 0 da Secundidade, que supõe 0 confronto; e o da Terceiridade, que se estabelece pela atuação de um "terceiro" que interpreta o mundo através de signos. Este último é o universo humano, embora possamos perceber qualidades do primeiro e ter experiências de confronto do segundo.
} 
Em resumo a convergência teórica sobre a linguagem literária entre os dois pensadores permite a postulação de um complexo "imagético"' (qualissigno hipoicônico) que não se identifica com o real, mas é percebido como novo por um "eu neutro", sempre "outro", cuja voz é a do "interpretante".

\section{Narrativa e diário}

Sem desmerecer as reflexões posteriores de Foucault sobre a autoria e a escrita de si (1966 e 1969), vamos retomar as ideias de Blanchot num pequeno ensaio publicado inicialmente em 1953 onde apresenta as características que distinguem o "diário íntimo" da "narrativa", ao mesmo tempo em que se esforça para encontrar nomes que se apliquem aos limites que os separam. Faz uso da expressão "lugar da imantação" como próprio à narrativa (ou ficção), "que atrai a figura real para os pontos em que ela deve se colocar, respondendo ao fascínio da sua sombra" (BLANCHOT, 2005, p. 271). Nesta passagem o sujeito da escrita (autor) surge como a "sombra" do eu, ou do "eu como o outro" que nos habita, mas que não costuma aparecer desse jeito no diário íntimo. Falar de "sombra" é abrir caminho para o desconhecido que nos conduz para detrás dos nossos sentimentos, no "espaço incandescente" (idem, p. 272) que a vida diária afasta e dissimula. Dessa forma, no "diário íntimo" é possível ser tempestuoso e dilacerado, enquanto na "narrativa", quando isso ocorre, há de existir um "centro de gravidade", um "lugar que expulsa as horas, dissipa o mundo" (idem). Cai-se, portanto, na narrativa, este lugar "da paixão e da noite" (idem) de onde se evola uma sinceridade abismal, totalmente distante daquele compromisso de sinceridade do autor do "diário íntimo". Na "narrativa" ele será conduzido por alguma força que procede, não só do seu inconsciente, mas também dos seus sentimentos mais extremados, reprimidos e condenados pela sociedade (ou superego).

No "diário íntimo" a datação coloca a escrita sob a proteção dos dias, assim como o calendário serve como âncora para proteger o autor da vertigem da "narrativa" que o arrastaria para um território desconhecido e temido. Daí se explica a presença no "diário íntimo" de certa verdade superficial, por vezes anódina e entediante, quando a escrita se restringe à narração de fatos da vida cotidiana. À exceção dos casos em que o "diário íntimo" é um lugar onde se depositam os "arredores do segredo" de uma "narrativa" que se constrói em paralelo, para Blanchot ele é uma tentativa de escape do silêncio, da loucura, da solidão e mesmo do desespero de não ter o que dizer e se torna assim uma dupla nulidade, duplo malogro, falso diálogo.

O par blanchotiano "narrativa vs. diário" corresponde em Derrida (1998) à oposição "ficção vs. testemunho" onde a figura do "terceiro" pode ser associada ao "interpretante" peirceano a quem cabe estabelecer a relação significativa entre o signo (ou texto) e o referente que, no primeiro caso, é imaginário ("narrativa” ou ficção) e, no segundo caso, uma suposta verdade ("diário íntimo" ou testemunho). No entanto a questão crucial é saber a que distância as categorias "narrativa"/ficção e "diário íntimo"/testemunho estão entre si, e ainda perceber se há um limite, identificável e nítido, entre ambas.

Diz Blanchot que o diário pode descambar para a narrativa. Diz Derrida que o testemunho pode ser ficcionado ou mesmo falseado em Morada; Maurice Blanchot (1998) onde se aprofun- 
da na análise do opúsculo publicado por Blanchot - O instante da minha morte - , e levanta a hipótese de que a obra se mantém na indiscernível fronteira entre a ficção e o testemunho pessoal do autor, com o objetivo político de embaralhar as denúncias de colaboracionismo com os nazistas ocupantes da França por ocasião da $2^{\text {a }}$ guerra. Num trabalho minucioso ao pé da letra, Derrida garimpa signos que sejam "rastos" do "crime" ou da "má-consciência" do crítico e colega sem, no entanto, alcançar uma conclusão segura que elimine a ambiguidade do relato, fazendo o texto resistir no entrelugar da ficção e do testemunho.

É frequente entre os críticos o desejo de alcançar uma classificação do texto lido sob o quadro de uma tradição com o fim de marcar a sua filiação, pesando influências e inovações, mas também de identificar as divergências em relação ao modelo. $\mathrm{O}$ formalismo e o estruturalismo foram pródigos em ações deste tipo e hoje, passado o vendaval da teorização moderna e pós-moderna, é possível retomar a diluição (ou "disseminação", na linguagem derridiana) para além do pânico diante do enigma, do paradoxo e do hibridismo que encontramos em obras literárias.

\section{Método e corpus}

Para abordar a fragilidade do conceito de "limite" em benefício de uma noção alargada de "limiar", é preciso observar as áreas de dissolução onde o fenômeno supostamente emerge. Em nosso caso a proposta se restringe a polemizar as distinções entre ficção e escrita de si, tendo como objeto de análise excertos das escritas de Maria Gabriela Llansol e Clarice Lispector.

Estas reflexões ocorrem num momento em que, já reconhecida a radicalidade da narrativa da escritora portuguesa, há que se lidar com as dificuldades para apresentá-la como uma experiência que parece ameaçar a noção engessada de literatura, tal como a autora assim se expressou ao tentar diluir a pretensa separação entre arte e vida: "Não há literatura. Quando se escreve só importa saber em que real se entra, e se há técnica adequada para abrir caminho a outros" (LLANSOL, 1998, p. 55). Aqui, além da atenção à "técnica adequada", a realidade plural se lhe afigura como algo a compartilhar. Desde cedo e ao longo de sua carreira no exílio, a autora sentiu a necessidade de se afastar das definições cristalizadas de literatura para melhor compreender a natureza da escrita. Mas, sem a pretensão de contar a história completa dessa desconstrução, que de resto se encaixa num movimento estudado por William Marx em L'adieu à la littérature; Histoire d’une dévalorisation, o nosso objetivo é desenvolver a possibilidade de uma leitura do literário (ou do ficcional) a partir de algumas entradas do seu primeiro diário ${ }^{4}$, Uma data em cada mão; Livro de Horas I (2009), observando a convivência ou transformação de registros que ultrapassam o teor meramente testemunhal. A publicação pode ser rotulada formalmente como "escrita de si" em edição que reproduz o material oriundo dos seus cadernos manuscritos da época (1972-1977), marcados cronologicamente por entradas do calendário, como é de praxe

\footnotetext{
${ }^{4}$ Cabe esclarecer que Llansol compôs e editou em vida três "diários", I, II e III, a partir das suas anotações diarísticas: Um falcão no punho (1985), Finita (1987) e Inquérito às quatro confidências (1996). Em 2009, um ano após a sua morte mas sob a sua supervisão, publica-se o Livro de Horas I, primeiro de uma série.
} 
no gênero. Desta edição não constam as passagens que a própria autora publicou em vida como parte de sua obra ficcional. ${ }^{5}$

Em direção oposta ensaia-se a leitura de Um sopro de vida (1978), de Clarice Lispector, como uma forma diferida de "escrita de si", mas classificada como "Romance brasileiro" na ficha catalográfica da edição analisada. A fortuna crítica da autora brasileira não se cansa de referir, ainda hoje, a perspectiva inovadora daquela escrita, muitas vezes justificada com declarações e comportamentos que a colocavam para além das regras e dos meios literários. Se na obra da autora portuguesa observam-se inúmeras passagens em que o modelo do diário se aprofunda ou cai em vertigem, abrindo-se à ficcionalidade, no caso de Clarice a sua suposta ficção em forma de vozes alternadas está sob a organização de uma voz "autoral" que dá unidade à obra como se fosse o autor polifacetado de um diário. Este derradeiro livro de Clarice, escrito em simultâneo à Hora da estrela, é um depoimento preliminar em masculino nas páginas iniciais e ainda nas demais partes ou "capítulos", por onde correm estas falas alternadas sob as rubricas dos personagens Autor e Angela. No diálogo ausente/presente entre tais vozes é possível surpreender uma "escrita de si" da autora brasileira que, de modo enviesado e dramático, produz no fim da sua vida um testemunho desdobrado em dois "eus" distintos, não-intercomunicantes mas organicamente superpostos, como se fossem duas vozes em uma, a da autora.

\section{Leituras}

Se o Uma data em cada mão; Livro de Horas I de Llansol se enquadra "oficialmente" na rubrica diário, numa leitura atenta percebe-se que o texto muitas vezes beira o abismo da narrativa. $\mathrm{E}$ se Um sopro de vida; Pulsações de Clarice está catalogado como narrativa ficcional, nem por isso deixa de revelar as pulsações derradeiras de um coração em agonia ao mesmo tempo em que produz a ficção de $A$ Hora da estrela.

Já se fez a contextualização da dicotomia "diário vs narrativa" proposta por Blanchot que, por fim, enalteceu a segunda em detrimento do primeiro. Também já foram mencionadas as ambiguidades (ou indecidibilidade) entre testemunho e ficção discutidas por Derrida num texto, por ironia, do próprio Blanchot. Como as formas jamais são puras em suas realizações, é mais oportuno considerar, não a definição filosófica ou literária de Belo, mas a experiência de leitura, cuja emoção não é passível de controle unicamente por classificações acadêmicas, embora a leitura deva estar rente à letra do texto. Com tais cautelas, percebe-se que o livro de Llansol não é um "diário íntimo" clássico; e que a obra de Clarice não é uma "narrativa” ficcional em plena forma. Há nuances a serem discutidas, já que ambas as obras transitam nos limiares entre uma e outra experiência de escrita.

\footnotetext{
${ }^{5}$ Ainda que esta excisão tenha sido autorizada pela autora, lamenta-se a impossibilidade de constatar visualmente, os momentos em que a escritora muda a sua letra ao passar do registro diarístico à ficção e vice versa na página publicada do Livro de Horas l; Uma data em cada mão, como se pode verificar no acervo visual dos seus cadernos manuscritos e digitalizados, mantidos no Espaço Llansol, em Lisboa.
} 


\title{
4.1. Llansol
}

Em Uma data em cada mão; Livro de Horas I, a escritora perambula entre o real e o irreal, faz uso de sua voz pessoal, mas por vezes se impessoaliza. Como mostra a entrada de 30 de Abril de 1972, domingo, há depoimentos prosaicos - "Alheamento da vida de trabalho de todos os dias: actividade da Escola, compras, preparação da comida" (LLANSOL, 2009, p. 25). Mas a escrita pode vir sob forma de poema, logo na abertura da primeira entrada do diário em 14 de Fevereiro de 1972:

\section{A cena primitiva}

A vida eterna não existe.

Sentou-se arranjando as saias, para assistir à produção do texto.

Este texto é um texto que assiste à produção do texto.

Este texto é a cena primitiva do texto.

A mulher não existe, mas é escrita por

(idem, p. 23)

Nesta obra que se prolonga em outros volumes, como Livro de Horas II, III, IV, V e VI, o excerto abaixo manifesta uma função hiponemática ou metalinguística, muito usada pela autora para refletir filosoficamente sobre temas que a perturbam, como é o caso das considerações sobre a relação entre a vida e a escrita. Além da data, a entrada do diário informa o lugar de onde o eu fala, a cidade belga onde ela iniciou o seu exílio:

\section{Lovaina (“Brasseur") 12 de Novembro de 1974}

\begin{abstract}
"Comprei este caderno para que, de certo modo, a experiência do tempo possa ser recuperada". E também porque a leitura de Fragments d'um Journal, de Mircea Eliade me deu tal prazer que pensei que, um dia, ler estes textos acumulados em estreita correlação com a "minha tensão de esvair-me e acumular-me em metamorfoses", me poderia proporcionar um prazer semelhante. E também por uma insaciável curiosidade intelectual: deter e desenvolver o que vem ao meu encontro, o que me desperta e eu transformo na escrita das metáforas. (idem, p. 60)
\end{abstract}

Constata-se nesta parte inicial da passagem o testemunho pessoal de Llansol sobre os motivos que a levaram a criar um diário: "Comprei este caderno para (...)". Como mostra o itálico da frase, o mais importante motivo seria, a princípio, a recuperação da experiência do tempo. No entanto outros motivos correlatos se impõem: poder ler com prazer no futuro "estes textos acumulados", que se mesclam com a sua tensão de esvair-se e acumular-se "em metamorfoses", conseguindo assim "deter e desenvolver" o que lhe vem ao encontro para ser transformado "em uma escrita de metáforas", ou seja, em literatura. A reflexão procede, portanto, de um ato cotidiano - a leitura do diário de um famoso escritor de livros, voltado aos estudos da religião e dos mitos - mas acaba por servir ao processo literário.

Ao lado de pensamentos mais fundos e prazerosos, questões pessoais do cotidiano invadem o texto, como a referência aos desafios (desgostos) em torno da produção de um livro sobre a experiência pedagógica de Llansol na Escola de Namur: 
Em resumo, comprei este caderno para poder efetuar uma síntese e observar o círculo montante que conduz à velhice, tal como a concebo: a imensa reflexão sobre o passado, a paz dos contrastes, a concentração no presente em que o futuro (imaginável) já está a fazer-se para sempre.

E também para sentir como está latente o livro sobre a Escola. E me desgosta. (idem, p. 60)

As contrariedades estão presentes como num diário íntimo - "O assunto deixa-me 'mal à l'aise"' (idem, p. 61) - e se mesclam à reflexão interrompida, marcando distinções entre vida e escrita, entre escrita de si e ficção,

No meu meditar, na minha experiência vivida, livro e Escola são inconciliáveis, o texto a engendrar-se é uma afirmação de labirinto, de desordem calculada, de redução a um caos que deve organizar-se, escrevendo-se de maneira imprevisível. (...) (idem, p. 61)

Contudo revelam-se, ironicamente, dificuldades para definir limites de qualidade entre uma e outra:

Observação:

Os bons escritores fazem os maus diários. Aceito fazer um mau diário.

(idem, p. 61)

Em resumo, nesta entrada de diário, Llansol reafirma a sua escolha pela escrita de ficção ou "narrativa" como "uma síntese" capaz de relacionar passado, presente e futuro (imaginável), ainda que para isso tenha de produzir "um mau diário" ao se afastar das regras do gênero. No entanto, mais adiante, ela emparelha a "narrativa" que está a produzir na época e a "escrita de si" onde explica o que faz: “Se não escrevo n'O Livro das Comunidades, escrevo aqui. Se não posso correr n'O Livro das Comunidades, tenho o contacto menor deste texto" (Llansol, 2009, p. 61). $\mathrm{Na}$ verdade, $\mathrm{O}$ Livro de Horas I não se enquadra de modo absoluto no padrão de um "diário íntimo", tal como definido por Blanchot, e traz toda sorte de escrita. Tal abertura promove uma constante ventilação entre vida e texto e responde pelo efeito prazeroso da leitura.

De modo inverso, ao lermos passagens de O Livro das comunidades, lá encontraremos elementos que nos endereçam à vida da própria autora, como nesta passagem final em que se mescla à figura de Ana de Penãlosa:

- Trabalhei entre os trinta e oito e os quarenta e três anos; mas agora preciso de recriar um novo lugar de repouso destinado somente ao saber, como na adolescência e na infância. (idem, 1977, p, 86)

Aqui a idade da figura equivale à idade de Llansol ao concluir o mesmo livro com uma referência geográfica e cronológica paratextual: "Abadia de Maredret, 2 de novembro de 1974". Nesta data, a autora, nascida a 24 de novembro de 1931, completava os mesmos 43 anos da figura que prosseguirá com relevo na rota da Trilogia de Rebeldes e da do Litoral do mundo.

Num caso, como no outro, a distinção entre os gêneros na escrita llansoliana se esfuma tanto na obra diarística, quanto na obra narrativa, graças basicamente ao poder das imagens que pontuam indistintamente as duas formas de escritura. Quando a autora afirma que sua proposta é não só de escrita, mas sobretudo de "escreviver", deixa clara a contaminação da ficção pela vida 
diária e desta pela ficção, o que a liberta das cláusulas de gêneros por ampliar o limiar entre eles. De modo análogo, a "voz narrativa" desliza entre a autora e a figura, ou entre um eu e um outro, assim como as imagens ocorrem tanto no texto ficcional quanto no diarístico, instabilizando o paradigma real vs ficcional. Na mesma Entrada de 24 de Janeiro de 1976, sábado, lê-se a alternância de registros entre o imagético e o testemunhal, revelando uma forma de "escrita de si" que alimenta o registro poético e vice-versa:

Eu vos escrevo

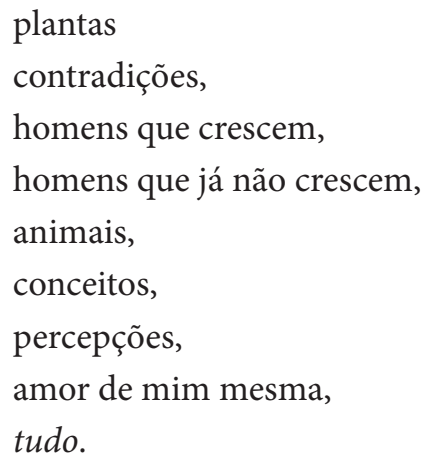

Fazer o pão, desenhar no pão sinais, liberta-me as mãos dos movimentos de minha rota. E a escrita se transforma num outro traçado, e tudo noutro mundo elaborado, histórico e livre. (idem, 2009, p. 116)

\subsection{Lispector}

Por sua vez, Um sopro de vida; Pulsações (1999) de Clarice Lispector desponta como sofisticada narrativa ficcional em que dois personagens e um narrador lançam seus pensamentos no papel, sob o comando de uma "voz narrativa" fantasmática e neutra, que "de fora" do "enredo", dispõe as falas e as partes/capítulos ao longo da obra. Se por um lado o título do livro - Um sopro de vida - remete ao mito bíblico da criação do homem por Deus, por outro lado é possível ler a obra como um exercício de vida e de metaescrita. O seu subtítulo - Pulsações - nos direciona à vida biológica sustentada minimamente pelo coração, mas sobretudo nos faz pensar na precariedade do vínculo vital que a qualquer hora pode se romper, calando a voz que se enuncia como Autor, Ângela ou narrador. Por força desta nomeação funcional tripartite, a obra parece habitar o "limiar" entre a "narrativa ficcional" de celebração da vida e o "testemunho de si" como despedida da vida. Ao considerarmos a coexistência de produção desta obra com a escritura de A hora da estrela, de caráter nitidamente ficcional, mais razão existe para situar Um sopro de vida num lugar de diferença quanto à sua ficcionalidade, aproximando-o do polo testemunhal. De todo modo trata-se de uma obra que causa impacto não exatamente em virtude dos acontecimentos que narra, sejam reais ou ficcionalizados (a rigor não há acontecimentos mas reflexões), e sobretudo porque lá não existem ações de enredo, mas antes a força de um poderoso fluxo de consciência(s) que escorre profunda e intensamente de duas ou três fontes, ou vozes a pensar e a escrever em simultâneo. Tais identidades são duplos ficcionais da autora mas também versões de uma "escrita de si" diferida que experimenta a volúpia do pensamento, o que justifica o seu caráter intenso, aleatório e descozido ao acumular os fatos, basicamente de natureza mental, embora o corpo não esteja ausente. 
Na passagem intitulada "Como tornar tudo um sonho acordado?" (LISPECTOR, 1999, p. 93 96), que pode ser considerada um introito ao Livro de Angela, o personagem Autor valoriza e imediatamente desvaloriza os fatos em favor dos não-fatos, a saber, as palavras e sua misteriosa função que conduz à desaparição de si ou à substituição de si pelas palavras:

AUTOR. - Mais importante que o texto é o fato.

Os fatos me atrapalham. Por isso é que agora vou escrever sobre não fatos, isto é, sobre as coisas e o seu mirabolante mistério.

É curiosa a sensação de escrever. Ao escrever não penso nem no leitor nem em mim: nessa hora sou - mas só de mim - sou as palavras propriamente ditas. (idem, p. 95)

A seguir, mas não em resposta ao Autor, Angela surge como seu duplo feminino, e adere às palavras, pouco importando o seu sentido prévio, desde que sejam amorosas. Manifesta-se como um eu em plena "escrita de si", ainda que seja um personagem que se aproxima do abismo que é o escrever, tal como seria numa "escrita do outro", ou "narrativa" no sentido blanchotiano de vertigem atrás referido. O que temos aqui afinal: um personagem de "romance" ou um duplo de Autor/Clarice numa "escrita de si"?

ÂNGELA .- Gosto de palavras. Às vezes me ocorre uma frase solta e faruscante, sem nada a ver com o resto de mim. Vou de agora adiante escrever neste diário (grifo nosso) em dias em que não haja mais o que fazer, as frases quase à beira de não ter sentido mas que soam como palavras amorosas. Dizer palavras sem sentido é minha grande liberdade. Pouco me importa ser entendida, quero o impacto das sílabas ofuscantes, quero o nocivo de uma palavra má. Na palavra está tudo. Quem me dera, porém, que eu não tivesse esse desejo errado de escrever. Sinto que sou impulsionada. Por quem?

Eu quero escrever com palavras tão agarradas umas nas outras que não haja intervalos entre elas e entre eu. (...) (idem, p. 95)

Imediatamente o Autor retruca, em molde de ficção ou "narrativa", ao dar à palavra um sentido vertiginoso, impróprio ao "diário íntimo":

AUTOR. - A palavra é o dejeto do pensamento. Cintila.

Cada livro é sangue, é pus, é excremento, é coração retalhado, é nervos fragmentados, é choque elétrico, é sangue coagulado escorrendo como lava fervendo pela montanha abaixo. (idem, p. 95-96)

Nos excertos acima o personagem qualifica a sua escrita como de "diário", no entanto, o fragmento faz parte de uma narrativa ou romance, o que reencena a instabilização de limites entre os gêneros. Sem adotar tal escolha, apesar de escrever no mesmo lugar, o Autor igualmente se mobiliza com as palavras, que "cintilam", como ele próprio diz, ou têm efeito "faruscante", como diz Angela que, ao final da passagem, explode numa recusa do indecidível e mergulha no corpo: “- Oh não quero mais me expressar por palavras: quero por 'beijo-te”' (idem, p. 96).

Sobre a escrita livre de Clarice, um crítico do Diário Carioca já apontava em 1950:

Duas suspeitas se insinuam no correr da leitura de "A cidade sitiada" e a acompanham até o fim. A primeira, que a autora não escreve propriamente um romance, mas algo que escapa aos esquemas 
conhecidos, misto de ficção, poesia, filosofia. A segunda que Clarice Lispector esconde na aparente obscuridade do livro intenções sibilinas, como se, ao invés de narrar, estivesse cifrando mensagem portadora do verdadeiro sentido, do sentido profundo da obra. (BRANCO, 1950)

\section{Conclusão}

Alinhar algumas perguntas pode ser uma opção para retomar o sentido que orientou o percurso de leitura. Serão o prazer ou o gozo critérios suficientes para classificar como literário o texto lido? Serão as imagens as responsáveis pelo sentimento estético e ético experimentado, quando sabemos que o Belo (Kant) ou o Admirável (Peirce) nos alivia do desamparo (Freud) da finitude? É possível diluir a distinção radical entre os gêneros e a partir daí postular um limiar aberto aos inesgotáveis sentidos e prazeres da leitura e da escrita?

Para não ficar na paralisia do indecidível - condenado em certa medida por Derrida em vista da impossibilidade dupla de não poder decidir e de não poder persistir no indecidível (DERRIDA, 2004, p. 8) -, não nos parece suficiente aplicar aos fragmentos lidos a pecha da ambiguidade como faz Blanchot ao encerrar o capítulo "A literatura e o direito à morte" de A parte do fogo (1997). Melhor seria dizer que tais textos desconstroem, não só o discurso, mas também a própria definição de arte literária, forjada e remodelada desde os antigos segundo categorias que definem "limites".

A rigor a escrita tende ao deslocamento por espaços "limiares". Como matéria verbal, percorre para cima e para baixo os degraus de significação operados pela linguagem, que vão da arbitrariedade do "símbolo", aos rastos do "índice" e às similaridades do "ícone", alcançando o que Peirce chama de "quase-objeto", signo poético que não é exatamente uma coisa, mas uma relação intrinsecamente cambiante que envolve um terceiro, o homem, sua finitude, e o outro. Mesmo Valéry que, segundo Pignatari, "detestava as imprecisões" (1968, p. 57), reconhece que "sem um à peu près" a vida não seria possível” (idem) O “à peu près é o 'quase’ que permite a descoberta, o mais ou menos heurístico" (idem) de Peirce, o "limiar" no lugar do "limite". Para Pignatari, este quase-signo ultrapassa dicotomias ao introduzir o terceiro como “(...) o zerograma de uma série estocástica ${ }^{6}$. Não é diacronia, nem sincronia; história, nem cosmos; ser, nem não-ser (...) - é uma relação, envolve um terceiro" (idem).

Segundo Peirce, o "ícone”, ao qual se filia a imagem literária, "é o signo da descoberta" pelo qual tenta compreender a especificidade deste Belo, ou kalós, mediante o seu sistema, buscando "a qualidade cuja presença imediata permite que se diga que seja kalós." (Collected Papers 2.199; citado em PIGNATARI, 1968, p. 53). Como tantos artistas filósofos, Peirce busca uma definição do objeto estético que "deve (...) ter uma quantidade (multidude) de partes de tal modo relacionadas umas às outras que confiram uma positiva e simples qualidade imediata à sua totalidade" (5.132; idem). É um ato de recepção praticado por um terceiro, pois "na fruição estética nos entregamos ou nos dedicamos à totalidade do Sentimento - especialmente a resultante da Qualidade do Sentimento

\footnotetext{
${ }^{6}$ Em teoria probabilística, o padrão estocástico é aquele cujo estado é indeterminado, com origem em eventos aleatórios ( https://pt.wikipedia.org/wiki/Estoc\%C3\%A1stico).
} 
total apresentada na obra de arte que estamos contemplando" (idem) com base na ideia de que "há um Sentimento que pode ser compreendido" (idem). Isto ocorre porque "A poesia [e a ficção] é uma espécie de generalização do sentimento e nessa medida é uma metamorfose do sentimento" (idem) que se produz por meio da "imagem", este signo hipo-icônico, "quase-objeto", "que se refere ao objeto que denota simplesmente em virtude de caracteres próprios (dele, signo) e que ele possui independentemente da existência ou não do objeto" (2.257; idem, p. 39, rodapé 16).

Também Blanchot, como já notamos, esboça uma teoria da imagem literária como aquilo que só se assemelha a si mesmo, tal qual o cadáver que rompe com a representação do ser que morreu, associando-se ao "estranhamento" imagético discutido no formalismo russo.

Resta responder ao que mais se destaca na escrita das autoras aqui aproximadas: complexos sígnicos carregados de qualidade a compartilhar. No caso de Llansol, o seu leitor ou legente pode se comover com o dia-a-dia envolvido no fulgor que a autora capta pela experiência corporal e que com ele satura o texto. Sentimentos e pensamentos se somam ao simples relato diarístico do cotidiano, fazendo-nos crer que a arte anda à nossa roda, e não apenas emoldurada numa categoria chancelada institucionalmente que rege a diferença entre o "real" e o "imaginário", ou entre o testemunho de um "eu" e a ficção de um "outro". A autora portuguesa, cuja lucidez teórica produziu muitos pronunciamentos sobre a sua arte, cunhou conceitos como "cena fulgor" para expressar passagens imagéticas de intensa "qualidade", assim como criou a noção autônoma de "textualidade" para substituir a representação verossímil do real.

No caso de Clarice, o leitor se abisma no mergulho de uma vida real que coloca a escrita no lugar da morte e assim sobrevive, até que finalize a produção simultânea dos livros e possa sancionar o hibridismo de Um sopro de vida e assinar a ficção de A hora da estrela, ao mesmo tempo em que faz oscilar a oposição entre as categorias do "eu" e do "outro". Os personagens do primeiro, Autor e Angela, nascem e se criam juntamente com Macabéa, do segundo livro em criação simultânea, todos como duplos clariceanos que convivem imagética e magicamente com a autora à beira-morte, oferecendo ao mundo a sua com-paixão solidária num tríptico estético que ameniza a dor do desamparo. Na penúltima e última seção (capítulo) de Um sopro de vida, a vida ainda pulsa mas a morte é o tema dominante no surdo diálogo em forma de drama entre o Autor e Ângela:

AUTOR. - (...) Ângela não morre a morte porque já morre em vida: é assim que ela escapa do final fatídico em tendo uma amostra de morte total em dias cotidianos. (...) (idem, p. 144)

ÂNGELA. - (...) Há em minha volta tantos movimentos que eu os pensei: a morte me espera. (...) O meu movimento mais puro é o da morte. (...) (idem p. 147)

AUTOR. - Ângela já aprendeu a aceitar as suas crises de medo: (...) (idem , p. 147) Para nunca morrer, Ângela prefere não existir. (...) (idem, p. 148)

ÂNGELA - Sinto que há um dedo que me aponta e me faz viver à beira da morte. Dedo de quem? (...) (idem , p. 151)

AUTOR. - Eu te vivo como se a morte já nos tivesse separado. (...) (idem, p. 155)

ÂNGELA - Está amanhecendo: ouço os galos. Eu estou amanhecendo. (...) (idem p. 159)

Parece impossível distinguir com nitidez os polos dos binômios examinados nos textos, seja o "eu" do "outro", seja a "realidade" do "imaginário". Ao contrário da noção de "limes" como "limite" e "margem", que negam permeabilidade e passagem entre fronteiras, o paradigma "limiar" emerge 
como espaço em que a imagem estética instabiliza a lógica binária na literatura e nas artes. Como produto de um trabalho (energia mental e física), a "imagem" mantém a sua independência em relação à realidade e ao autor que poderiam lhe servir, respectivamente, de cenário prévio e de suporte vocal. Fruto de um corp'a'screver (expressão de Llansol) ou de uma relação arte/vida ou, aqui, arte/morte (desejo de Clarice), toda palavra lançada no branco do papel repercute de forma mais ou menos opaca ou luminosa no interpretante. O gesto autoral pode ser intencionado, mas se realiza em plenitude pelo deslizamento entre o "eu" e o "outro" e pela aceitação do acaso trazido da "realidade" ou do "imaginário", que chega como um prêmio de beleza que se pode compartilhar.

Desse modo talvez seja desejável trazer de volta a arte para a vida, como fazem Lispector e Llansol e como faziam os pré-socráticos que "costumavam expressar-se em linguagem poética" (BORNHEIM, 1984, p. 91).

\section{REFERÊNCIAS}

AGAMBEN, Giorgio. A linguagem e a morte; um seminário sobre o lugar da negatividade. Trad. Henrique Burigo (Belo Horizonte: Editora UFMG, 2006).

BLANCHOT, Maurice. O espaço literário. Trad. Álvaro Cabral, Rio de Janeiro: Rocco, 1987.

BLANCHOT, Maurice. La voix narrative. In: L'entretien infini. Paris: Gallimard, 1969, p. 556-567.

BLANCHOT, Maurice. A parte do fogo. Trad. Ana Maria Scherer. Rio de Janeiro: Rocco, 1997.

BLANCHOT, Maurice. O livro por vir. Trad. Leyla Perrone Moisés. São Paulo: Martins Fontes, 2005.

BRANCO, Carlos Castelo. Meios e fins do romance: notas sobre "A cidade sitiada". In: Diário carioca. Rio de Janeiro: 22/01/1950.

BORNHEIM, Gerd A. Literatura e filosofia: o espaço da estética. In: KHÉDE, Sonia Salomão (org.). Os contrapontos da literatura; Arte, ciência e filosofia. Petrópolis: Vozes,1984,p. 91-101.

COSTA LIMA, Luiz. A metamorfose do silêncio; análise do discurso literário. Rio de Janeiro: Eldorado, 1974.

DERRIDA, Jacques. Morada; Maurice Blanchot. Trad. Silvina Rodrigues Lopes. Viseu: Edições Vendaval, 2004.

HARVEY, David. Condição pós-moderna. Trad. Adail Ubirajara Sobral e Maria Stela Gonçalves. 5.ed. São Paulo: Edições Loyola, 1992.

LLANSOL, Maria Gabriela. Uma data em cada mão. Livro de Horas I. Org. João Barrento e Maria Etelvina Santos. Lisboa: Assírio \& Alvim, 2009.

LLANSOL, Maria Gabriela. O livro das comunidades. Porto: Afrontamento, 1977.

LISPECTOR, Clarice. Um sopro de vida; Pulsações. Rio de Janeiro: Rocco, 1999.

PEIRCE, Charles Sanders. Escritos coligidos. In: Pensadores, v. XXXVI. São Paulo: Abril Cultural, 1974, p.7-192.

PEIRCE, Charles Sanders. Semiótica. Trad. J.T.Coelho Neto. São Paulo: Perspectiva, 2000.

PIGNATARI, Décio. Semiótica e literatura. São Paulo: Perspectiva, 1968. 